\title{
Ameliorative Role of Melatonin on CA1 of Hippocampus and Frontal Cortex in Induced Social Isolation in Adult Male Albino Rat
}

\author{
AMANY E.M. HAMOUD, M.D. \\ The Department of Anatomy and Embryology, Faculty of Medicine, Cairo University, Cairo, Egypt
}

\begin{abstract}
Background: Social Isolation (SI) which means absence or insufficient contact with others is a key factor in psychiatric disorders development, which might be necessary for effective psychological treatment as social rehabilitation. Social experience during the infantile period affects brain function and behaviour in rodents, dogs and human.
\end{abstract}

Aim of Study: The current study was designed to elucidate the neuroprotective role of MT on experimentally-induced SI on CA1 of rat hippocampus and frontal cortex.

Material and Methods: Twenty adult albino rats were divided into four groups, control, sham control, SI and SI + MT. The Body Weight (BW), Brain Weight (BrW) were determined. Brain sections were subjected to histological, morphometric, biochemical and statistical studies.

Results: SI induced various histological changes in both hippocampus and frontal cortex in the form of degeneration and absent neurons. SI also caused a significant (sig) increase in area \% of caspase 3 and TNF Immunoexpression (IE) were recorded. Sig decrease in the activity of Total Antioxidant Capacity (TAC), Brain Derived Neurotropic Factor (BDNF), Superoxide Dismutase (SOD) activity, Acetyle Choline Esterase (ACHE), dopamine level as well ARC gene, and a sig increase in Malondialdehyde (MDA) levels, FOS gene, serotonin and AB-42. Concomitant administration with MT improved sig the previously mentioned changes.

Conclusion: SI might lead to various neurological degenerations as indicated by the histological, morphometric, biochemical changes. These changes were ameliorated by concomitant administration with MT.

Key Words: Brain - Hippocampus - Social isolation - Melatonin - Antioxidant.

\section{Introduction}

SOCIAL experience during the infantile period affects brain function and behaviour in rodents, dogs and human [1]. Previous studies showed that the brain function decrease as a result of brain

Correspondence to: Dr. Amany E.M. Hamoud, The Department of Anatomy and Embryology, Faculty of Medicine, Cairo University, Cairo, Egypt myelination affection [2]. Social Isolation (SI) means absence or insufficient contact with others is a key factor in psychiatric disorders development, which might be necessary for effective psychological treatment as social rehabilitation [3]. Previously, social interaction improve both mental and physical health and reduce the risk of cognitive impairment and development of dementia [4].

Social isolation is one of the major reason for psychosocial stress and responsible for increased incidence of vascular and neurological diseases. Moreover, SI aggravates morbidity and mortality following acute injuries such as stroke or myocardial infarction and increases oxidative stress, inflammatory reaction and synaptic plasticity. All the previous mechanisms might be predisposing factors for Alzheimer's Disease (AD) occurrence [5]. Chronic stress and isolation is widely used in animal model of mental disorders such as schizophrenia and depression, because SI induces behaviour and chemical changes as reduction of BrainDerived Neurotrophic Factors (BDNF) in rat hippocampus [6].

Hippocampus is formed of Cornus Ammonis (CA1, CA2, CA3 CA4 regions) and the dentate gyrus. CA1 is the zone that is most sensitive and vulnerable to various insults and oxidative stress [7]. Increased oxidative stress underlay the adverse effects of SI that raise concern about antioxidants administration [8]. Melatonin (MT) is a hormone secreted from the pineal gland with a regulatory and neuroprotective function. Its level is disturbed in some neurological conditions such as AD and Parkinson's disease, which indicates its involvement in the pathophysiology of these diseases [9]. As apart of its antioxidant role, MT neutralizes free radical and reduces tissue damage in the brain through its direct scavenging activity and indirect antioxidant actions, as denoted by high levels of 
melatonin in the Cerebrospinal Fluid (CSF) relative to its concentration in the blood. Therefore it gives the brain extra protection from oxidative stress [10].

The aim of the present study was to elucidate the possible neuroprotective role of MT on experimentally-induced SI in CA1 of rat hippocampus and frontal cortex.

\section{Material and Methods}

Animals: The current study was carried out on 20 adult male albino rats, 3-5 months old weighing 150-200g. The rats were obtained from Animal House of Kasr Al-Ainy in December 2018, Faculty of Medicine, Cairo University. Rats were housed for one week for environmental adaptation under standard laboratory conditions at $25 \pm 1^{\circ} \mathrm{C}$ with 12 hours light/dark cycle. They were fed on a constant adequate nutrition diet and allowed free access to drinking water ad libitum. The experimental work was conducted in accordance with the guidelines of the committee of cairo univerisity. Animals were housed in stainless-steel cages, at a temperature of $25 \pm 1^{\circ} \mathrm{C}$. Isolated rats were housed individually in cages for six weeks, while socialized rats were randomly paired and housed in cages. Animals were kept under adequate environmental conditions.

Rats were divided into four groups as follow:

- Control group: Consisted of five rats that received $1 \mathrm{ml} 0.9 \mathrm{NaCl}$ saline solution intraperitoneal (I.P).

- Sham group: Consisted of five rats that received MT $5 \mathrm{mg} / \mathrm{kg}$ body weight (IP) [11], daily at night for six weeks.

- Socially isolated group (SI): Consisted of five rats socially isolated for six weeks and received $1 \mathrm{ml} 0.9 \mathrm{NaCl}$ saline solution IP.

- Socially isolated and MT treated group (SI+ $M T)$ : Consisted of five rats that were socially isolated and received MT $5 \mathrm{mg} / \mathrm{kg}$ body weight IP daily at night for six weeks.

\section{Drug:}

MT was received from Amoun Pharmaceutical Industries Co, Cairo, Egypt. MT was dissolved in $1 \mathrm{ml} 0.9 \% \mathrm{NaCl}$ saline solution.

\section{Methods:}

- Determination of the Body Weight (BW) and Brain Weight (BrW) of all rats in different groups.

- Rats were sacrificed, the brain tissues were dissected and washed with ice-cold saline. The absolute brain weight ratio to body weight (organ weight/body weight X100) were measured for each rat and recorded.

- For all groups, brain tissues were homogenized in saline. Determination of B-amyloid (AB-42) content: It was measured in brain tissue homogenate by using ELISA kit supplied by (MyBioSource, Inc, SanDiego, USA, Product Number MBS702915), according to the manufacturer's instructions [12]

- Determination of Acetyle Choline Esterase (ACHE) activity: It was measured in brain tissue homogenate using commercially available test kit supplied by Sigma-Aldrich Co. (St. Louis, MO, USA), Product Number MAK119 [13]

- Assessment of oxidative stress markers Malanodialdehyde (MDA), Superoxide Dismutase (SOD) and Total Antioxidant Capacity (TAC) [14] . SOD activity was achieved relying on the ability of the enzyme to inhibit the phenazine methosulphate mediated reduction of nitroblue tetrazolium dye. The increase in absorbance at $560 \mathrm{~nm}$ for $5 \mathrm{~min}$ is measured. Finally, determination of TAC was assessed by the reaction of antioxidants with a defined amount of exogenously provide $\mathrm{H}_{2} \mathrm{O}_{2}$ [15].

- Determination of Brain Derived Neurotropic Factor (BDNF): It was measured in brain homogenate by using ELISA Kit supplied by (MyBioSource, Inc., SanDiego, USA, Product Number MBS494147), according to the method of [16].

- Determination of brain inflammatory mediators $(T N F-\alpha)$ : TNF- $\alpha$ was done in brain tissue homogenate by using ELISA Kit, Product Number (RTA00, SRTA00, PRTA00) [16].

- Dopamine and serotonin were assessed in tissue homogenate according to [17].

- Fos and Arc gene were measured in tissue homogenate using Quantitative Polymerase Chain Reaction (qPCR) [18].

- Paraffin blocks were prepared and 5 mick sections were subjected to the following histological studies:

1- Hematoxylin and eosin (H \& E) stain [19]

2- Caspase 3 immunostaining: The marker for apoptosis. $7 \mathrm{ml}$ of rabbit polyclonal Ab (RB1197-R7) (Lab Vision Corporation, USA) was prediluted ready to use solution stored at 2$8^{\circ} \mathrm{C}$. The + ve tissue control was a specimen 
of human tonsil. Caspase 3 +ve cells showed cytoplasmic reaction [20].

3- Tumour necrosis factor: Primary Antibody. $7 \mathrm{ml}$ of rabbit polyclonal $\mathrm{Ab}$ (Catalog Number: IW-PA1079) was ready to use solution. The +ve tissue control was a specimen of human tonsil. Negative control: Omit primary antibody, isotype control, absorption control Blocking: 2-5\% normal serum to reduce unspecific background staining; $0.5-3 \% \mathrm{H}_{2} \mathrm{O}_{2}$ to block endogenous peroxidase activity; avidin/biotin to block endogenous biotin activity if necessary [21].

- Morphometric study: Leica Qwin 500 LTD (Cambridge, UK) computer assisted image analysis system was used, the area\% of caspase 3 and TNF Immuno Expression (IE) in hippocampus and frontal cortex were estimated using binary mode. The measurements were done in 10 high power fields, of 10 sections in each speciemen.

- Statistical study: Quantitative data were summarized as means and standard deviations and compared using one-way analysis-of-variance (ANOVA). Any significant ANOVA was followed by post hoc Tukey test to detect which pairs of groups caused the significant (sig) difference. $p$ values $<0.05$ were considered statistically sig [22]. Calculations were made on Statistical Package of Social Science (SPSS) software version 16.

\section{Results}

General observation: No clinical signs of toxicity were noticed neither in SI nor in SI + MT groups.

Mean $B W$ and $B r W$ : No statistically difference was detected between groups concerning both BW and $\mathrm{BrW}$ (Table 1).

Table (1): Mean of absolute BW and BrW in different groups.

\begin{tabular}{lcc}
\hline Groups & BW Mean \pm SD & BrW Mean \pm SD \\
\hline Control group & $153.20 \pm 42.08$ & $2.22 \pm 0.5$ \\
Sham group & $160.80 \pm 48.09$ & $2.11 \pm 0.4$ \\
SI group & $156.80 \pm 40.01$ & $1.76 \pm 0.3$ \\
SI + MT group & $155.60 \pm 40.50$ & $2.10 \pm 0.4$ \\
\hline
\end{tabular}

Histological changes: There was no histological differences between Control and MT groups, examination of H\&E stained sections showed that the hippocampus proper is formed of Cornu Am- monis CA1, CA2, CA3, CA4 regions and the dentate gyrus. CA1 and CA2 formed of zone of small pyramidal cells while CA3 and CA4 formed of zone of large pyramidal cells. CA4 projects into concavity of dentate gyrus and is formed of small granule cells. Areas in between crowded zones of pyramidal cells constitutes the molecular layer which consists of axons and dendrites, glial cells, and scattered nerve cells (Fig. 1). CA1 regions revealed three layers: Polymorphic, pyramidal and molecular. Pyramidal layer composed of layers of small pyramidal cells. Both the polymorphic and molecular layer apparently normal cells (Fig. 2a). Closer observation showed pale nuclei and basophilic cytoplasm of pyramidal neurons, few oligodendroglia, microglia and astrocytes (Fig. $2 b$ ). Frontal cortex sections showed normal appearance of neurons in molecular, external granular, external pyramidal, inner granular, inner pyramidal and pleomorphic layers (Fig. 2c). Closer observation demonstrated pale nuclei and basophilic cytoplasm of pyramidal neurons, stellate neurons, granule cells, with few oligodendroglia microglia and astrocytes (Fig.2d). SI group: In CA1 of hippocampus revealed focal areas of absent neurons (Fig. 3a), some areas showed dark nuclei of some neurons and multiple microglia (Fig. 3b). Frontal cortex sections showed some large and small masses (Fig. 3c). Closer observation of frontal cortex showed acidophilic masses surrounded by clear areas and containing dark nuclei, with multiple microglia (Fig. 3d). SI+MT group: In CA1 of hippocampus showed apparently normal neurons (Fig.4a). Few neurons appeared with dark nuclei and few microglia (Fig. 4b). Frontal cortex showed some small masses (Fig. 4c) and small acidophilic masses surrounded by clear areas and few microglia (Fig. 4d).

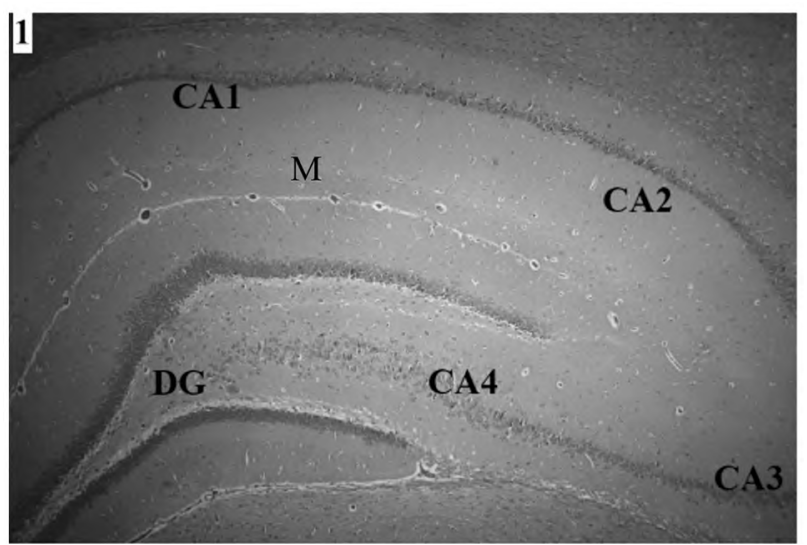

Fig. (1): Photomicrograph of hippocampus proper from control group showing three areas of hippocampus (CA1, CA2 and CA3) and the Dentate Gyrus (DG). Molecular layer located inside the concavity of $\mathrm{CA}$ and of DG (M). (H \& E X40). 

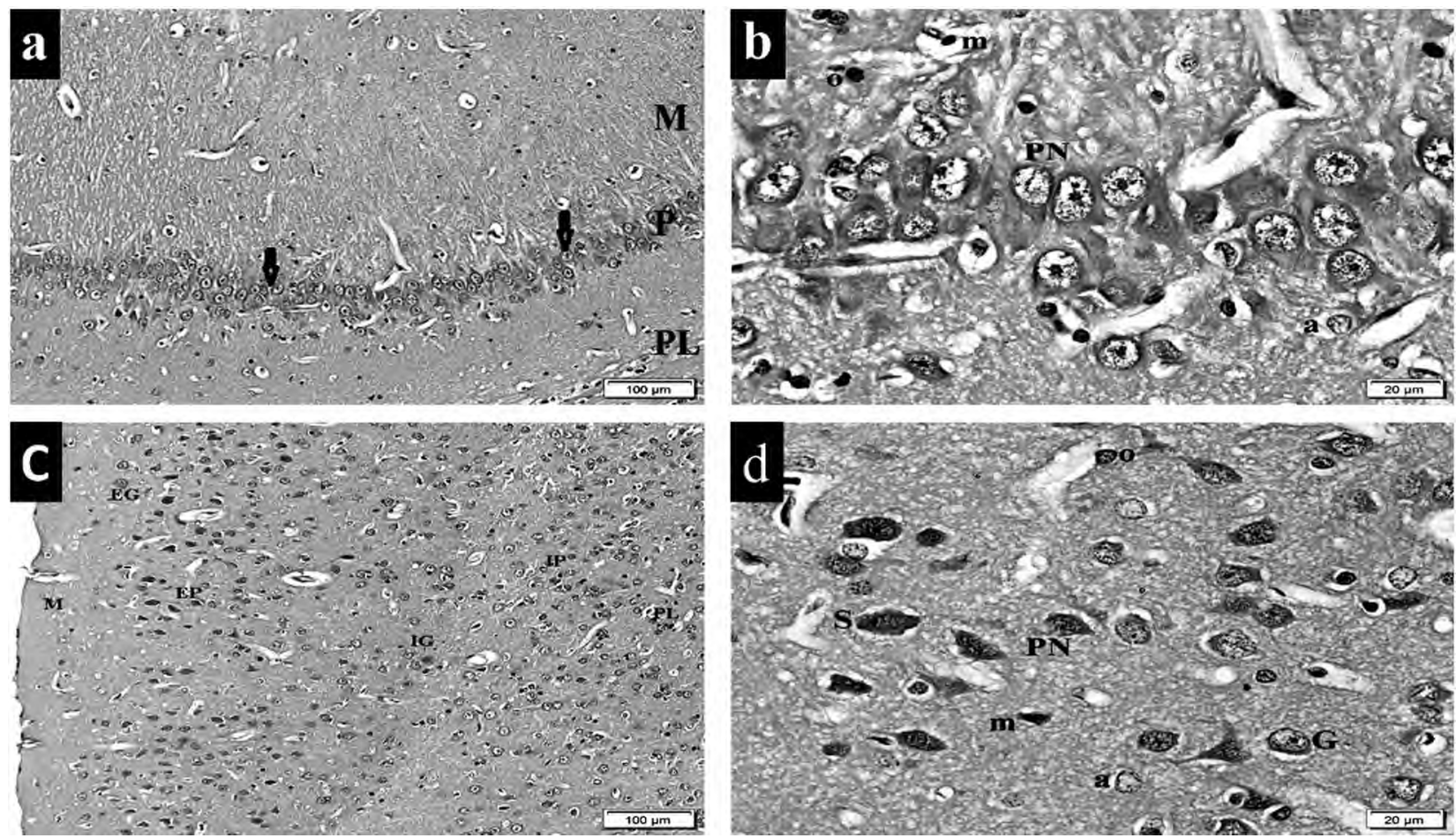

Fig. (2): Control groups: A) Sections in CA1 of hippocampus showing multiple regular rows of the small pyramidal cells with normal appearing neurons (arrows). CA1 regions revealed three layers: Polymorphic (PL), pyramidal (P) and molecular (M) (H \& E X 100). B) Higher magnification of hippocampus showing pale nuclei and basophilic cytoplasm of pyramidal neurons (PN), few oligodendroglia (o), microglia (m) and astrocytes (a) (H \& E X400). C) Frontal cortex showing normal appearance of neurones in molecular (M), external granular (EG), external pyramidal (EP), inner granular (IG), inner pyramidal (IP) and pleomorphic layers (PL) (H \& E X100). D) Higher magnification of frontal cortex showed pale nuclei and basophilic cytoplasm of pyramidal neurons (PN), stellate neurons (S), granulecell (G), with few oligodendroglia (o) microglia (m) and astrocytes (a) (H \& E X400).
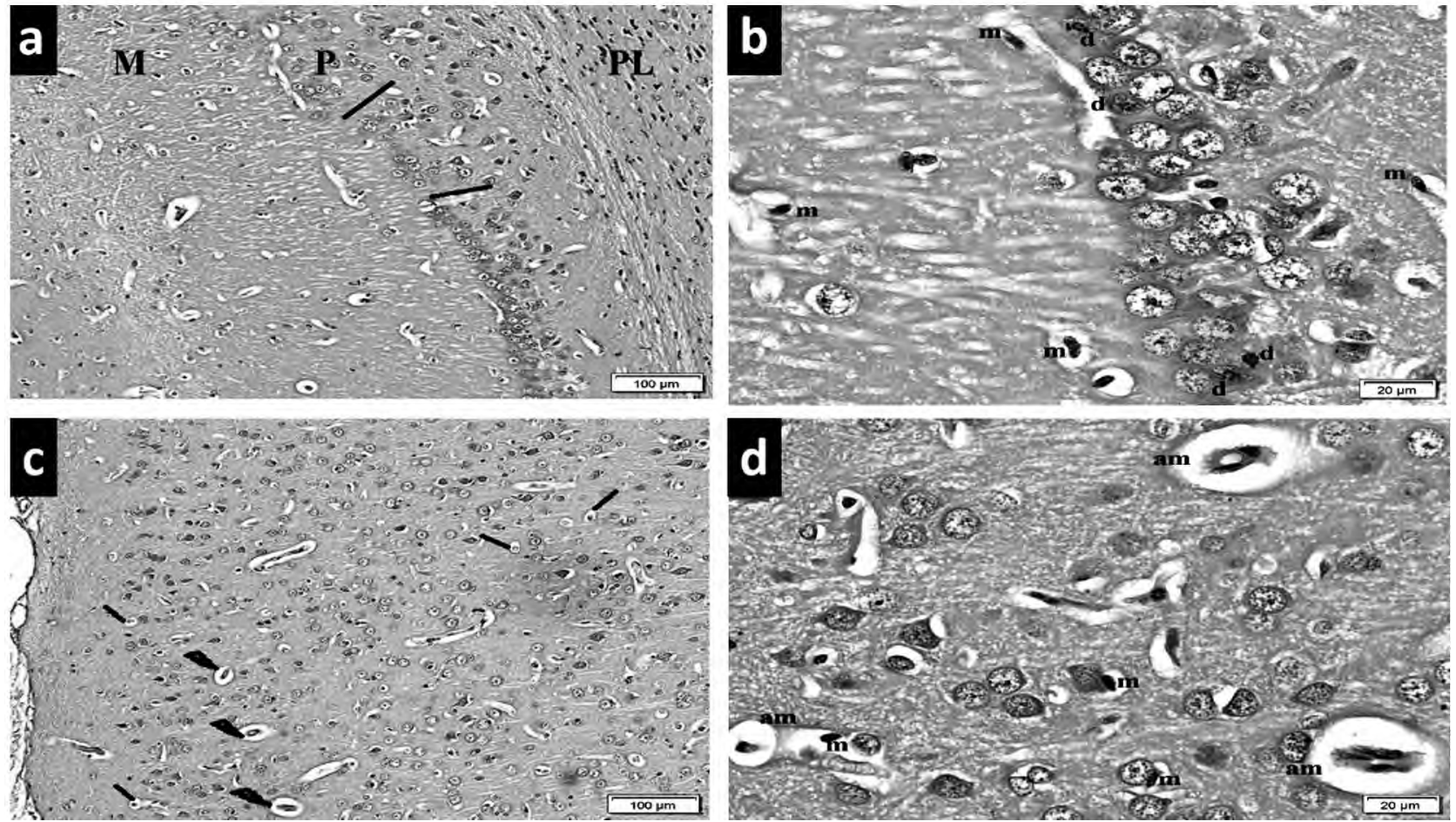

Fig. (3): SI group: A) Section in CA1 of hippocampus showing focal areas of absent neurons (lines) N.B: Polymorphic (PL), pyramidal (P) and molecular (M) (H \& E X100). B) Higher magnification showing dark nuclei of some neurons (d) and multiple microglia (m) (H \& E X400). C) Section in frontal cortex showing some large (zigzag arrows) and small masses (lines) (H \& E X100). D) Higher magnification of frontal cortex showed large and small acidophilic masses (am) surrounded by clear areas and containing dark nuclei, with multiple microglia (m) (H \& E X400). 

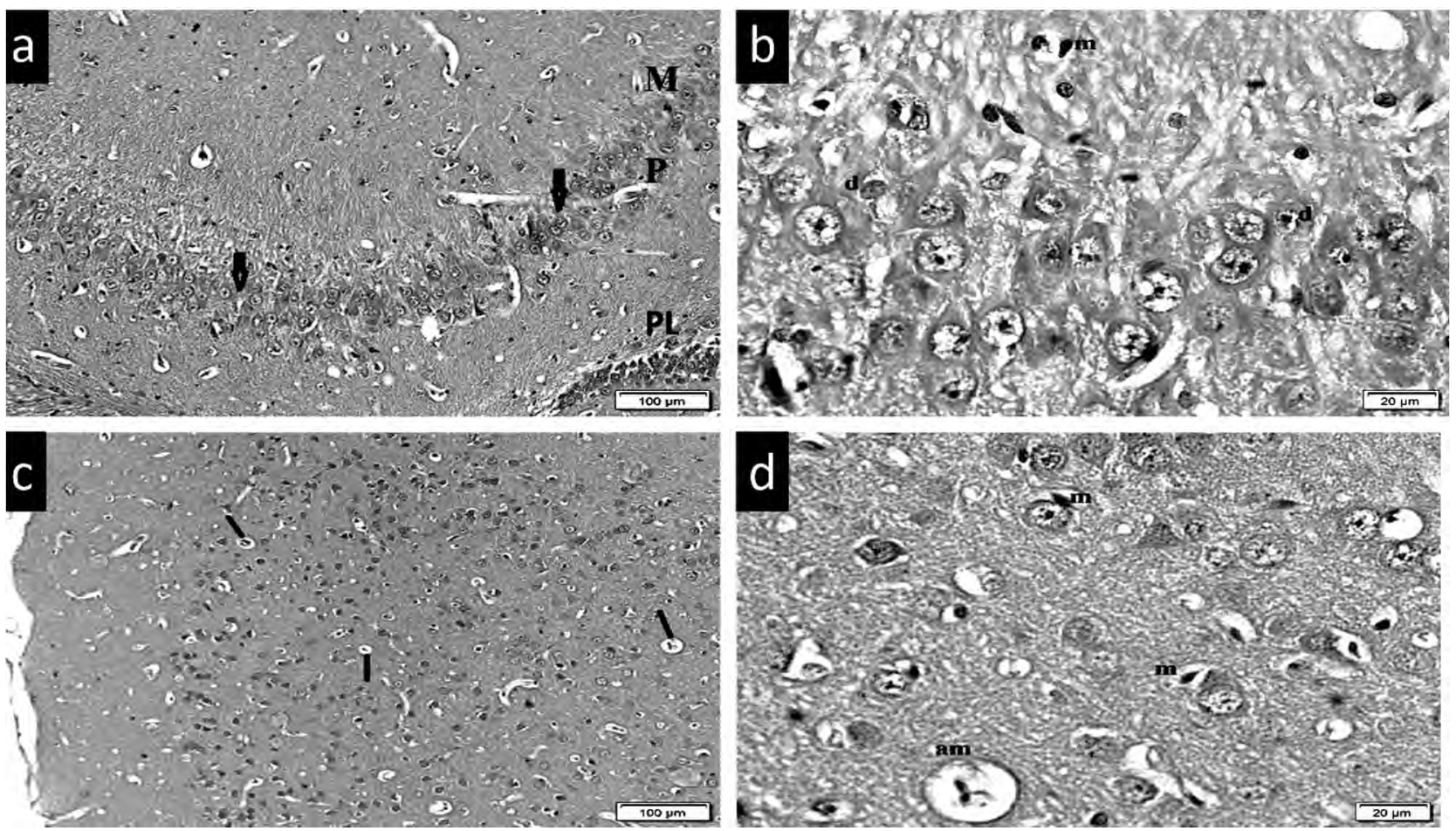

Fig. (4): SI and MT group: A) Section CA1 in hippocampus showing apparently normal neurons (arrows). N.B: Polymorphic (PL), pyramidal (P) and molecular (M) (H \& E X100). B) Section in hippocampus showing few neurons with dark nuclei (d) and few microglia (m) (H \& E X400). C) Section in frontal cortex showing some small masses (lines) (H \& E X100). D) Higher magnification of frontal cortex showing a small acidophilic masses (am) surrounded by clear areas and few microglia (m) (H \& E X400).

Immunohistochemical changes: Sections in hippocampus and frontal cortex showed negative reaction of caspase $3 \mathrm{IE}$ in both control and MT groups (Figs. 5a,b). While sections in hippocampus and frontal cortex showed positive reaction of caspase 3IE in some neurons in SI group (Figs. $5 \mathrm{c}, \mathrm{d})$. In SI+MT group positive reaction of caspase 3IE in few neurons were found (Figs. 5e,f). Regarding TNF immunostaining negative IE were found in control and MT groups in both hippocampus and frontal cortex (Figs. 6a,b). Hippocampus in SI group showed positive IE among the neurons and vessels (Fig. 6c), while in frontal cortex the extent of positivity were more among multiple neurons and vessels (Fig. 6d). Hippocampus of SI+MT group showed positive IE among few vessels (Fig. 6e), while in frontal cortex showed positive IE among few neurons and few vessels (Fig. 6f).

Morphometric changes: The mean area $\%$ of caspase 3 and TNF IE indicated a sig decrease in SI+MT group compared to SI group in both hippocampus and frontal cortex sections. (Table 2).

\section{Biochemical changes:}

1- BDNF, SOD and TAC changes: BDNF, SOD and TAC mean differences showed a sig de- crease in SI group compared to other groups, while in SI+MT group a sig increase was noticed compared to SI group (Table 3).

2- MDA and TNF mean changes: The of MDA and that of TNF showed sig increase in SI group compared to other groups. While, in SI+MT group a sig decrease was found compared to SI group (Table 4).

3- ARC and FOS gene changes: The mean of ARC gene showed a sig decrease in SI group compared to other groups. On the other hand, the mean of FOS gene revealed a sig increase in SI group compared to other group. While, in SI+MT group a sig increase was found of ARC gene mean compared to SI group and a sig decrease of FOS gene mean was detected in SI+MT group compared to SI group (Table 5).

4-ACHE, AB-42, dopamine and serotonin changes: Mean of ACHE and dopamine showed sig decrease in SI group than other groups and a sig increase in SI+MT group compared to SI group. While, mean of AB-42 and serotonin showed sig increase in SI group compared to other group and a sig decrease in SI+MT group compared to SI group (Table 6). 

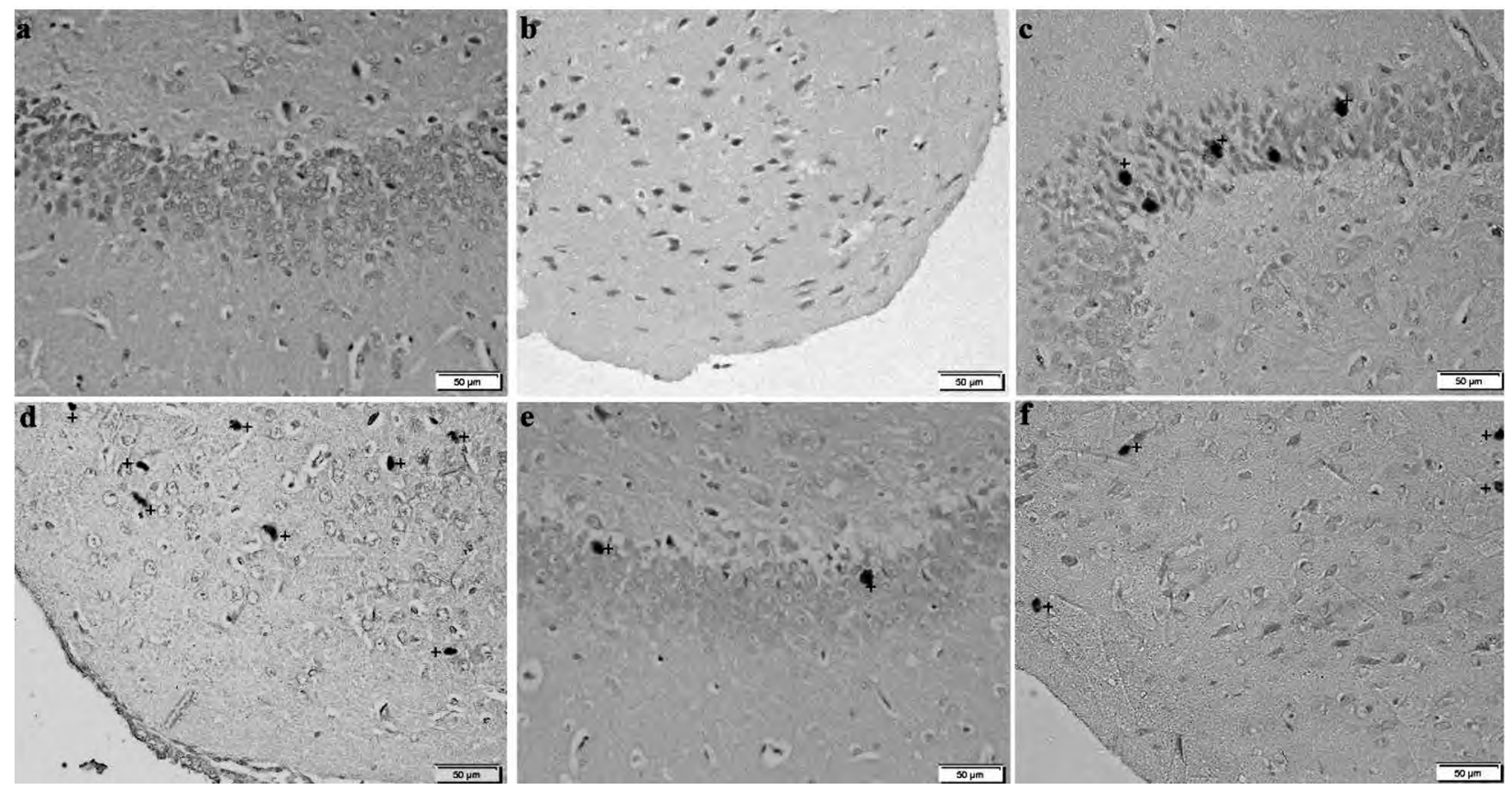

Fig. (5): Sections of caspase 3 immunostaining X200: A) Section in hippocampus of control groups showing negative reaction of caspase 3 IE. B) Section in frontal cortex of control groups showing negative reaction of caspase 3 IE. C) Section in hippocampus in SI group showing positive reaction of caspase 3IE in some neurons (+). D) Section in frontal cortex in SI group showing positive reaction of caspase 3 IE in some neurons (+). E) Section in hippocampus of SI and MT group showing positive reaction of caspase 3IE in few neurons (+). F) Section in frontal cortex of SI and MT group showing positive reaction of caspase 3IE in few neurons $(+)$.
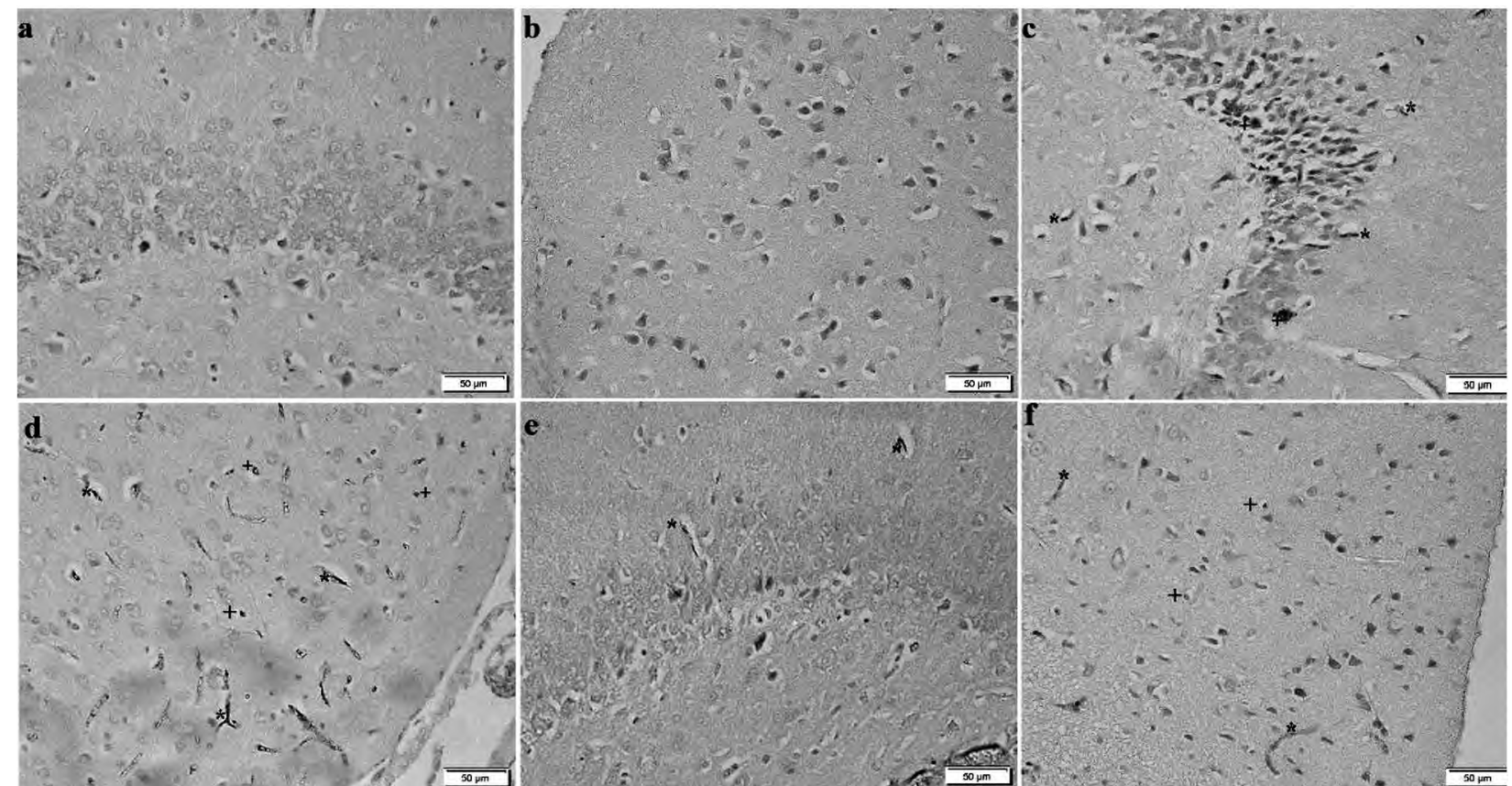

Fig. (6): Sections of TNF immunostaining X200: A) Section in hippocampus of control groups showing negative IE. B) Section in frontal cortex of control groups showing negative IE. C) Section in hippocampus of SI group showed positive IE among the neurons $(+)$ and vessels $\left(^{*}\right)$. D) Section in frontal cortex showing positive IE among multiple neurons (+) and vessels (*). E) Section in hippocampus of SI and MT group showed positive IE among few vessels (*). F) Section in frontal cortex showing positive IE among few neurons (+) and few vessels (*). 
Table (2): Mean area\% of caspase 3 IE and +ve IE in TNF.

\begin{tabular}{lcccc}
\hline & $\begin{array}{c}\text { Mean +ve } \\
\text { caspase IE } \\
\text { hippocampus }\end{array}$ & $\begin{array}{c}\text { Mean +ve } \\
\text { caspase IE } \\
\text { frontal } \\
\text { cortex }\end{array}$ & $\begin{array}{c}\text { Mean +ve } \\
\text { TNF IE } \\
\text { hippocampus }\end{array}$ & $\begin{array}{c}\text { Mean +ve } \\
\text { TNF IE } \\
\text { Frontal } \\
\text { cortex }\end{array}$ \\
\hline $\begin{array}{l}\text { Control group } \\
\text { SI group }\end{array}$ & $61.00 \pm 15.8$ & $55.00 \pm 15.8$ & $35.00 \pm 10.4$ & $60.00 \pm 16.7$ \\
& $29.21^{\wedge} \pm 8.3$ & $25.51^{\wedge} \pm 5.9$ & $14.51^{\wedge} \pm 3.5$ & $29.51^{\wedge} \pm 7.6$ \\
\hline
\end{tabular}

$\operatorname{Sig} p \leq 0.05 .^{\wedge}$ sig compared to SI groups.

Table (3): Mean changes of BDNF, SOD and TAC in different groups.

\begin{tabular}{llll}
\hline Groups & $\begin{array}{c}\text { BDNF } \\
\text { Mean } \pm \text { SD }\end{array}$ & $\begin{array}{c}\text { SOD } \\
\text { Mean } \pm \text { SD }\end{array}$ & $\begin{array}{c}\text { TAC } \\
\text { Mean } \pm \text { SD }\end{array}$ \\
\hline Control group & $115.89 \pm 30.4$ & $4.38 \pm 1.4$ & $100.48 \pm 30.4$ \\
Sham group & $117.50 \pm 35.3$ & $4.62 \pm 0.9$ & $108.32 \pm 32.2$ \\
SI group & $70.18^{*} \pm 20.9$ & $1.98^{*} \pm 0.5$ & $61.66^{*} \pm 18.4$ \\
SI + MT group & $99.30^{\wedge} \pm 25.5$ & $3.74^{\wedge} \pm 1.01$ & $87.02^{\wedge} \pm 20.8$ \\
\hline
\end{tabular}

*: Statistically sig different than other three groups.

^: Statistically sig different than SI group.

Table (4): Mean changes in MDA and TNF in different groups.

\begin{tabular}{lll}
\hline Groups & MDA \pm SD & TNF \pm SD \\
\hline Control group & $14.68 \pm 4.03$ & $20.74 \pm 5.9$ \\
Sham group & $10.72 \pm 2.5$ & $19.44 \pm 5.8$ \\
SI group & $38.36^{*} \pm 10.4$ & $76.64^{*} \pm 20.5$ \\
SI + MT group & $16.38^{\wedge} \pm 4.5$ & $43.52^{\wedge} \pm 12.5$ \\
\hline
\end{tabular}

*: Statistically sig different than other three groups.

$\wedge$ : Statistically sig different than SI group.

Table (5): Mean changes in ARC and FOS gene in different groups.

\begin{tabular}{lll}
\hline Groups & ARC \pm SD & FOS \pm SD \\
\hline Control group & $1.36 \pm 0.3$ & $1.01 \pm 0.3$ \\
Sham group & $1.44 \pm 0.4$ & $0.84 \pm 0.2$ \\
SI group & $0.23^{*} \pm 0.1$ & $4.26^{*} \pm 1.1$ \\
SI + MT group & $0.72^{\wedge} \pm 0.06$ & $2.48^{\wedge} \pm 0.8$ \\
\hline
\end{tabular}

Table (6): Mean changes in ACHE, AB-42, dopamine and serotonin in different groups.

\begin{tabular}{lcccc}
\hline Groups & $\begin{array}{c}\text { ACHE } \\
\pm \mathrm{SD}\end{array}$ & $\begin{array}{c}\text { AB-42 } \\
\pm \mathrm{SD}\end{array}$ & $\begin{array}{c}\text { Dopamine } \\
\pm \mathrm{SD}\end{array}$ & $\begin{array}{c}\text { Serotonin } \\
\pm \mathrm{SD}\end{array}$ \\
\hline Control group & $46.28 \pm 13.5$ & $36.40 \pm 8.4$ & $46.1 \pm 12.8$ & $17.68 \pm 5.3$ \\
Sham group & $48.00 \pm 14.5$ & $33.62 \pm 9.4$ & $48.80 \pm 15.6$ & $16.66 \pm 4.3$ \\
SI group & $25.50^{*} \pm 7.5$ & $73.78^{*} \pm 20.3$ & $35.28^{*} \pm 8.1$ & $28.38^{*} \pm 7.3$ \\
SI + MT group & $37.92^{\wedge} \pm 10.2$ & $50.74^{\wedge} \pm 16.3$ & $45.24^{\wedge} \pm 9.7$ & $19.74^{\wedge} \pm 6.1$ \\
\hline
\end{tabular}

*: Statistically sig different than other three groups.

^: Statistically sig different than SI group.

\section{Discussion}

The present study investigated the histological, histochemical, immunohistochemical morphometric and biochemical changes that may develop in rat CA1 hippocampus and frontal cortex experimentally exposed for SI and the possible protective role of MT. No sig difference was recorded in neither BW nor BrW between different groups as a result of SI, contrary to the result of some authors who found that physical or emotional stress reduced weight gain [23], while others pointed out that mice exposed to SI, BW increase sig compared to socialized groups, those authors referred this weight gain to decrease in contact and playing with mates resulting in a compensatory mechanism and increased food intake [24].

Histological changes in CA1of hippocampus in SI group revealed darkly stained pyknotic nuclei, which indicated apoptosis and degeneration. Further support for these results was obtained from the morphometric results, as the mean area \% of Caspase $3+v e$ cells showed a sig increase in SI group compared to other groups. The previous changes were confirmed by biochemical results in the form of sig increase in AB-42 in SI group. AB-42 is an end product of the Amyloid Precursor Protein (APP), whose deposition is neurotoxic and could induce apoptosis of neurons [25]. The neurotoxicity of $A \beta-42$ is strongly related to oxidative stress with increased production of hydrogen peroxide and lipid peroxides in neurons [26]

Caspases are responsible for protein degradation and cleaving of amino acids, once caspases are activated, there seems to be a sequence to cell death [27]. The caspase-3 activates cytoplasmic endonucleases that degrade the nuclear materials and proteins that followed by DNA fragmentation [28]. Area \% of caspase 3 that have been measured in the current work revealed a sig increase in SI group compared to the control groups. It has been implicated that caspase- 3 activation is the principal factor in apoptotic cell death [29].

In the present study, degenerative changes were noticed in hippocampus of SI group in the form of areas of absent neurons, which were confirmed by sig decrease in BDNF levels compared to other groups. BDNF influences neurons of the central and peripheral nervous system by supporting the survival of the existing neurons, encourage the neurogenesis and affect learning and memory. Similar findings were reported before [30]. On the contrary, increase in BDNF expression levels in brain of mice exposed to SI were reported [31].

In the current work, SI group showed multiple large acidophilic masses with dark nuclei in frontal cortex. One of these explanation of these masses is that apoptotic nuclei of several degenerated neurons unite together and form masses [32]. The previous results were confirmed by morphometric results which revealed a sig increase in +ve TNF 
IE as well biochemical result in the form of sig increase of TNF-a in SI group. TNF-a is one of the major proinflammatory response mediators in brain tissue and its increase lead to neurotoxicity and cellular damage.

Reactive Oxygen Species (ROS) generation causing damage of the neuronal cell membrane, proteins and nucleic acids and subsequently decrease in brain function. ROS can be indirectly evaluated by elevated MDA levels. In the current study a sig increase of MDA and sig decrease in TAC and SOD levels were observed in SI group compared to other groups. This means that SI leads to oxidative stress and ROS generation. This findings raise the concern about antioxidants role in improving learning and memory deficits secondary to brain function decrease associated with SI. The mean of FOS gene revealed a sig increase in SI group compared to other groups in the current work. The increase in FOS gene was related to oxidative stress and many authors studied the relation between activation of this gene transcription and ischemic brain injury. This increase might be explained by the need for gene products to repair that injury [33].

Serotonin level in the current work revealed a sig increased in SI group compared to other group, serotonin is well known to effectively impact mood, particularly depression, which might explain its increase in SI group. The increase in serotonin levels was attributed to decrease in BDNF [34].

Histological picture of SI + MT revealed apparently normal neurons in both hippocampus and frontal cortex, this was confirmed by morphometric results as a sig decrease in the mean area \% of +ve caspase 3 IE and TNF IE were recorded in the present work. That might be related to the recovery state of the tissue and decline in degeneration process. Co-administration of MT resulted in a sig increase in SOD and TAC levels and decrease MDA level due to its antioxidant effects [8] Dopamine expression in the current study was sig increased in SI + MT group compared to other groups, in contrary to many authors who concluded that SI resulted in increased dopamine expression compared to socialized animals, but still with unclear mechanism [35]. Previously, dopamine release inhibition by MT in specific areas of central nervous system as hypothalamus and hippocampus was observed [36].

Improvement of histological picture of SI + MT was confirmed by biochemical result in the form of increased ACHE sig as compared to SI group. Acetylcholine and ACHE neuro-transmittors are a key factor in learning and memory and maintaining the nervous system [37]. This finding is in agreement with previous study who studied the relation between ACHE decline and decrease brain function, memory and learning ability [8]. On the contrary to this finding, no sig change in ACHE between socialized and isolation-reared mice were noticed [38]

Arc gene expression affect learning and memory and observed in certain areas of central nervous system and it is one of the effectors of the BDNF, dopaminergic and serotonin signalling [39]. Arc is involved in generation of new synapses and maintenance of old ones required for some plasticity mechanisms such as Long-Term Potentiation (LTP) and long-term depression [40]. The relation between Arc and dopamine seems to be in both direction, in animal model that arc gene was deleted from the whole brain and a downregulation of dopamine levels in the cortex was found [41], contrary to the present work in which Arc gene was sig increased and sig decrese in dopamine level in SI + MT group. Similar findings were reported as SI in rodents and animal model of depression, a marked reduction in ARC levels in the hypothalamus, the hippocampus and the frontal cortex were noted [42].

\section{Conclusion:}

SI might led to various neurological degenerations as indicated by the histological ,morphometric, biochemical changes. These changes were ameliorated by concomitant administration of MT.

\section{References}

1- BICK J., FOX N., ZEANAH C. and NELSON C.A.: Early deprivation, atypical brain development, and internalizing symptoms in late childhood. Neuroscience, 342: 140-53, 2017.

2- LIU J., DIETZ K., De LOYHT J.M., PEDRE X., KELKAR D., KAUR J., VIALOU V., LOBO M.K., DIETZ D.M., NESTLER E.J., DUPREE J. and CASACCIA P.: Impaired adult myelination in the prefrontal cortex of socially isolated mice. Nat. Neurosci., 15: 1621-3, 2012.

3- MAKINODAN M., IKAWA D., YAMAMURO K., et al.: Effects of the mode of re-socialization after juvenile social isolation on medial prefrontal cortex myelination and function. Sci. Rep., 7 (1): 5481-90, 2017.

4- KHODAIE B., LOTFINIA A.A., AHMADI M., LOTFINIA M., JAFARIAN M., KARIMZADEH F., COULON P. and GORJI A.: Structural and functional effects of social isolation on the hippocampus of rats with traumatic brain injury. Behav. Brain Res., 278: 55-65, 2015.

5- FRIEDLER B., CRAPSER J. and McCULLOUGH L.: One is the deadliest number: The detrimental effects of 
social isolation on cerebrovascular diseases and cognition. Acta Neuropathol., 129: 493-509, 2015.

6- MURÍNOVÁ J., HLAVÁČCOÁ N., CHMELOVÁ M. and RIECANSKY' I.: The Evidence for Altered BDNF Expression in the Brain of Rats Reared or Housed in Social Isolation: A Systematic Review. Front. Behav. Neurosci., 11: 101-11, 2017.

7- LEE S.G., YOO D.Y., JUNG H.Y., NAM S.M., KIM J.W., CHOI J.H., YI S.S., WON M.H., YOON Y.S., HWANG I.K. and MOON S.M.: Neurons in the hippocampal CA1 region, but not the dentate gyrus, are susceptible to oxidative stress in rats with streptozotocin-induced type 1 diabetes. Neural. Regen. Res., Mar., 10 (3): 451-6, 2015.

8- ALI A.A., KHALIL M.G., ELARINY H.A. and ABUELFOTUH K.: Study on Social Isolation as a Risk Factor in Development of Alzheimer's Disease in Rats. Brain Disord. Ther., 6: 230, 2017.

9- REITER R.J., MAYO J.C., TAN D.X., SAINZ R.M., ALATORRE-JIMENEZ M. and QIN L.J.: Melatonin as an antioxidant: Under promises but over delivers. Pineal Res., 61 (3): 253-78, 2016.

10- TAN D.X., MANCHESTER L.C. and REITER R.J.: CSF generation by pineal gland results in a robust melatonin circadian rhythm in the third ventricle as a unique light: Dark signal. Med. Hypotheses, 86: 3-9, 2016.

11-NASIRAEI-MOGHADAM S.N., PARIVAR K., AHMADIANI A., MOVAHHEDIN M. and VAEZ MAHDAVI M.R.: Protective Effect of Melatonin against InequalityInduced Damages on Testicular Tissue and Sperm Para meters. Int. J. Fertil Steril., 7 (4): 313-22, 2014.

12- SHOKRI-KOJORI E., WANG G.J., WIERS C.E., DEMIRAL S.B., GUO M., KIM S.W., LINDGREN E., RAMIREZ V., ZEHRA A., FREEMAN C., MILLER G., MANZA P., SRIVASTAVA T., De SANTI S., TOMASI D., BENVENISTE H. and VOLKOW N.D.: P-Amyloid accumulation in the human brain after one night of sleep deprivation. Proc. Natl. Acad. Sci. USA, 115 (17): 4483-8, 2018.

13-ALREFAIE Z. and ALHAYANI A.: Vitamin D_improves decline in cognitive function and cholinergic transmission in prefrontal cortex of streptozotocin-induced diabetic rats. Behav. Brain Res., 287: 156-62, 2015.

14- ŻEBROWSKA E., MACIEJCZYK M., ZENDZIANPIOTROWSKA M., ZALEWSKA A. and CHABOWSKI A.: High Protein Diet Induces Oxidative Stress in Rat Cerebral Cortex and Hypothalamus. Int. J. Mol. Sci., 20 (7): 1547-63, 2019.

15- KORACEVIC D., KORACEVIC G., DJORDJEVIC V., ANDREJEVIC S. and COSIC V.: Method for the measurement of antioxidant activity in human fluids. J. Clin. Pathol., 54: 356-61, 2001.

16- MEIS S., ENDRES T. and LESSMANN V.J.: Postsynaptic BDNF signalling regulates long-term potentiation at thalamo-amygdala afferents. Physiol., 590 (1): 193-208, 2012.

17- NATALIA MIEKUS, ILONA OLEDZKA, DARYA HARSHKOVA, IVAN LIAKH, ALINA PLENIS, PIOTR KOWALSKI and TOMASZ B ACZEK: Comparison of Three Extraction Approaches for the Isolation of Neurotransmitters from Rat Brain Samples. Int. J. Mol. Sci., 19 (6): 1560, 2018.
18-HEROUX N.A., OSBORNE B.F., MILLER L.A., KAWAN M., BUBAN K.N., ROSEN J.B. and STANTON M.E.: Differential expression of the immediate early genes cFos, Arc, Egr-1, and Npas4 during long-term memory formation in the context preexposure facilitation effect (CPFE). Neurobiol. Learn Mem., 147: 128138, 2018.

19- KIERNAN J.K.: Histological and Histochemical methods. In: Theory and practice. 3 rd ed, Arnold Publisher, London, New York and New Delhy, 111-62, 2001.

20- SUN W., SU Q., CAO X., SHANG B., CHEN A., YIN H. and LIU B.: High expression of polo-like kinase 1 is Associated with early development of hepatocellular carcinoma. Int. J. Genomics., 2014: 312130, 2014.

21- AKASH M.S.H., REHMAN K. and LIAQAT A.: Tumor Necrosis Factor-Alpha: Role in Development of Insulin Resistance and Pathogenesis of Type 2 Diabetes Mellitus. J. Cell Biochem., 119 (1): 105-10, 2018.

22- EMSLEY R., DUNN G. and WHITE I.: Mediation and moderation of treatment effects in randomized controlled trials of complex interventions. Stat. Methods Med. Res., 19 (3): 237-70, 2010.

23- WARREN B.L., VIALOU V.F., INIIGUEZ S.D., ALCANTARA L.F., WRIGHT K.N., FENG J., KENNEDY P.J., LAPLANT Q., SHEN L., NESTLER E.J. and BOLAÑOS-GUZMÁN C.A.: Neurobiological sequelae of witnessing stressful events in adult mice. Biol. Psychiatry, 73: 7-14, 2013.

24- SIAL O.K., WARREN B.L., ALCANTARA L.F., PARISE E.M. and BOLANOS-GUZMAN C.A.: Vicarious social defeat stress: Bridging the gap between physical and emotional stress. J. Neurosci. Methods, 258: 94-103, 2016.

25- TINGTING WANG, YALING CHENG, HAIBIN HAN, JIE LIU, BO TIAN and XIAOCUI LIU: miR-194 Accelerates Apoptosis of A $\beta$ 1-42-Transduced Hippocampal Neurons by Inhibiting Nrn1 and Decreasing PI3K/Akt Signaling Pathway Activity. Genes (Basel), 10 (4): 31327, 2019.

26- HSIAO Y.H., CHANG C.H. and GEAN P.W.: Impact of social relationships on Alzheimer's memory impairment: mechanistic studies. J. Biomed. Sci., 25 (1): 3. J. Cell Biochem. 2018 Jan., 119 (1): 105-10, 2018.

27- SAKAI W. and SUQASAWA K.: FANCD2 is a target for caspase 3 during DNA damage-induced apoptosis. FEBS Let t., 588 (20): 3778-85, 2014.

28- MOSADEGH M., HASANZADEH S. and RAZI M.: Nicotineinduced damages in testicular tissue of rats; evidences for bcl-2, p53 and caspase-3expression. Iran J. Basic Med. Sci., 20 (2): 199-208, 2017.

29- MILLER I., MIN M., YANG C., TIAN C., GOOKIN S., CARTER D. and SPENCER S.L.: Ki67 is a graded rather than a binary marker of proliferation versus quiescence. Cell reports, 24 (5): 1105-12, 2018.

30- VIANA BORGES J., SOUZA De FREITAS B., ANTONIAZZI V., De SOUZA DOS SANTOS C., VEDOVELLI K., NAZIASENO PIRES V., PALUDO L., MARTINS De LIMA M.N. and BROMBERG E.: Social isolation and social support at adulthood affect epigenetic mechanisms, brain-derived neurotrophic factor levels and behavior of chronically stressed rats. Behav. Brain Res., 366: 36-44, 2019. 
31- KUMARI A., SINGH P., BAGHEL M.S. and THAKUR M.K.: Social isolation mediated anxiety like behavior is associated with enhanced expression and regulation of BDNF in the female mouse brain. Physiol. Behav., 158: 34-42, 2016.

32- BASSIONY H.S., ZICKRI M.B., METWALLY H.G., ELSHERIF H.A., ALGHANDOUR S.M. and SAKR W.: Comparative Histological Study onthe Therapeutic Effect of Green Tea and Stem Cells in Alzheimer's Disease Complicating Experimentally Induced Diabetes. Int. J. Stem. Cells, 8 (2): 181-90, 2015.

33- ZHAI K.1., KONG X., LIU B. and LOU: Bioinformatics analysis of gene expression profiling for identification of potential key genes among ischemic stroke. J. Medicine (Baltimore), 96 (34): e7564, 2017.

34- TANEL MÄLLO,a KADRI KÕIV,a INDREK KOPPEL,b KARITA RAUDKIVI,a AIN UUSTARE,c AGO RINKEN,c TÕNIS TIMMUSK,b and JAANUS HARROa: Regulation of extracellular serotonin levels and brain-derived neurotrophic factor in rats with high and low exploratory activity. Brain Res., 1194 (5): 110117, 2008.

35- YORGASON J.T., CALIPARI E.S., FERRIS M.J., KARKHANIS A.N., FORDAHL S.C. and WEINER J.L., JONES S.R.: Social isolation rearing increases dopamine uptake and psychostimulant potency in the striatum. Neuropharmacology, 101: 471-9, 2016.

36- ZISAPEL N.: Melatonin-dopamine interactions: From basic neurochemistry to a clinical setting. Cell Mol. Neurobiol., 21 (6): 605-16, 2001.
37- YANG W.N., HU X.D., HAN H., SHI L.L., FENG G.F., LIU Y. and QIAN Y.H.: The effects of valsartan on cognitive deficits induced by aluminum trichloride and $\mathrm{d}$ galactose in mice. Neurol. Res., 36: 651-8, 2014.

38- KODA K., AGO Y., YANO K., NISHIMURA M., KOBAYASHI H., FUKADA A., TAKUMA K. and MATSUDA T.: Involvement of decreased muscarinic receptor function in prepulse inhibition deficits in mice reared in social isolation. Br. J. Pharmacol., 162: 763-72, 2011.

39- MASTWAL S., CAO V. and WANG K.H.: Genetic feed back regulation of frontal cortical neuronal ensembles through activity dependent arc expression and dopaminergic input. Front. Neural. Circuits., 10: 100, 2016.

40- MINATOHARA K., AKIYOSHI M. and OKUNO H.: Role of immediate early genes in synaptic plasticity and neuronal ensembles underlying the memory trace. Front. Mol. Neurosci., 8: 78, 2016.

41- MANAGÒ F., MEREU M., MASTWAL S., MASTROGIACOMO R., SCHEGGIA D., EMANUELE M., De LUCA M.A., WEINBERGER D.R., WANG K.H. and PAPALEO F.: Genetic disruption of Arc/Arg3.1 in mice causes alterations in Dopamine and neurobehavioral phenotypes related to schizophrenia. Cell Rep., 16 (8): 2116-28, 2016.

42- OKADA R., MATSUMOTO K., TSUSHIMA R., FUJIWARA H. and TSUNEYAMA K.: Social isolation stressinduced fear memory deficit is mediated by downregulated neuro-signaling system and Egr1 expression in the brain. Neurochem. Res., 39: 875-82, 2014.

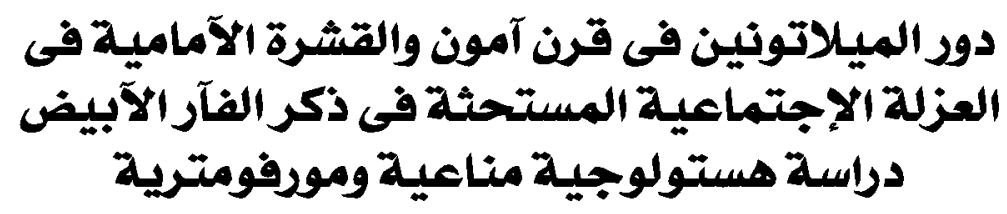

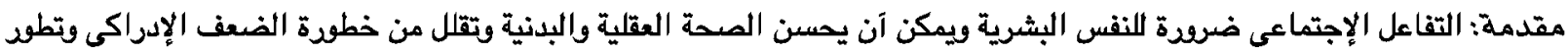

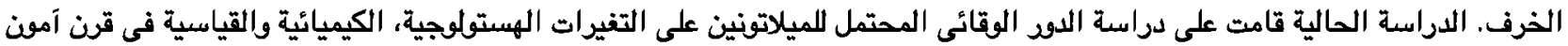

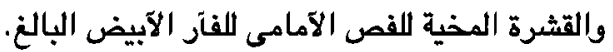

الهدف من الدراسة: لقد تم تصميم الدراسة الحالية لتوضيح الدود الوقائى المحتمل لحماية الخلايا العصبية للميلاتونين عن الدراسة

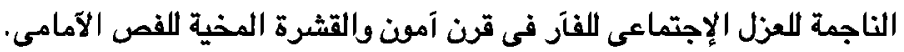

المواد والطرق : تم تقسيم عشرين فارَاً من فئران الآلينو إلى آربع مجموعات، مجموعتين مراقبة، مجموعة العزل الإجتماعى ومجموعة العزل الإجتماعى مع الميلاتونين. وتم تحديد ونن الجسم وكذالك ونن المخت وتم آخذ عينات من المخ ودراستها هستولوجياً، قياسياً، كيميائياً وإحصائياً.

النتائج: العزل الإجتماعى قد آحدث عدة تفيرات هستولوجية وتدمير فى بعض الخلايا فى كلا من قرن آمهن والقشرة المخية للفص الآمامى.

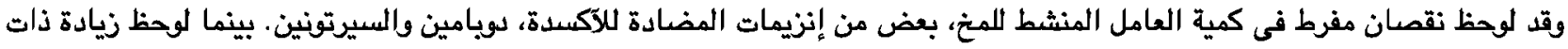

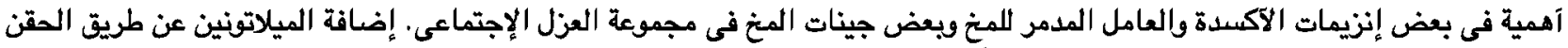

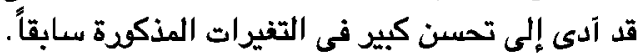

الخخلاصةّ: العزل الإجتماعى قد آحلث تغيرات هستولوجية، شكلية، قياسية، وكيميائية في قرن آمهن والقثرة المخية للفص الآمامى للفئران

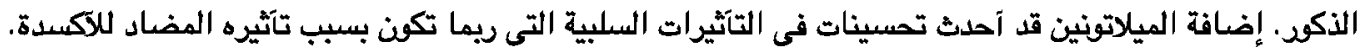

